International Journal of Business Management and Economic Review

Vol. 5, No. 01; 2022

ISSN: 2581-4664

\title{
UK MILLENIALS' PURCHASE INTENTIONS: WHAT FACTORS ARE INFLUENCING THEIR ADOPTION OF MOBILE APPS SHOPPING?
}

\author{
Dr. Yan Liang ${ }^{\mathrm{a}}$, Sid Ghosh $^{\mathrm{b}}$ and Naimot Oyeyemi ${ }^{\mathrm{c}}$ \\ ${ }^{a}$ Senior Lecturer, Department of Marketing, Strategy \& Innovation, Business School, Bournemouth University, \\ United Kingdom \\ ${ }^{\mathrm{b}}$ Senior Lecturer, Department of People \& Organisation, Business School, Bournemouth University, United \\ Kingdom \\ undergraduate student, Business School, Bournemouth University, United Kingdom
}

http://doi.org/10.35409/IJBMER.2022.3363

\begin{abstract}
The purpose of this paper is to understand the factors that serve as motivation and deterrents for UK Millennials' intention to purchase via mobile phones from retails' Applications. A total of 213 completed and valid questionnaires were collected and data were analysed by Exploratory Factor Analysis and confirmatory factor analysis. Furthermore, Structural Equation Modelling of AMOS graphics was used to identify the effect and relationship of independent variables on their dependent variables in this study. The findings of this research indicated that discomfort, insecurity, optimism, perceived ease of use determine UK Millennials' use of Mobile applications shopping. Moreover, the outcome showed a significant influence of discomfort and optimism on perceived ease of use of M-shopping and a negative causal relationship between insecurity and use of mobile phones for online shopping. The study also confirmed that perceived ease of use mobile application impacts the purchase intention of young consumers. A limited number of studies have discussed the factors influencing the adoption process of Mobile applications shopping and purchase intention focusing on Millennials in the United Kingdom. Therefore, this research fills in the research gap and explores the factors that influence Millennials to use mobile applications to purchase products online, and to understand how the change in new technology has changed their buying behaviours.
\end{abstract}

Keyword: Mobile application shopping, UK Millennials, purchase intension, TAM, TRI.

\section{INTRODUCTION}

In more recent years, with smartphone ownership booming, the mobile commerce market is growing rapidly (Grabham and Jones 2018; Pahwa 2018). The popularity of consumers purchase behaviour has shifted from traditional high street retails to $\mathrm{m}$ - commerce, which they are able to use mobile internet connectivity and mobile payments wherever and whenever (Sagar 2013). Consumers are turning to their smartphones to shop, m-commerce having an impact on the consumer decision-making process and their overall buying behaviour (Karam 2017). In 2016 Mshopping increased the "online retail spending in the UK to a record high of $£ 133 \mathrm{bn}$ " (PWC, 2016) and 18\% of online sales were carried out using mobile phones in 2017 (IMRG, 2017). To accommodate the increased consumer use of mobile phones for shopping, many retailers now have mobile phone applications available in addition to their mobile-compatible websites (Milnes, 


\section{International Journal of Business Management and Economic Review}

Vol. 5, No. 01; 2022

ISSN: 2581-4664

2015), these developments in M-shopping presents a highly effective marketing technique that provides consumers with additional shopping platforms. Due to its convenience, M-shopping is becoming the "go-to" for shoppers, with many choosing to look at a product in store, and then switching to their phones to get a better deal instead. Therefore, consumers are holding more power over retailers due to m-commerce having an impact on the consumer decision-making process and their overall buying behaviour (Karam 2017).

Bolton et al., (2013) claims that purchase behaviour of Millennials has been heavily influenced by the use and availability of technology, they have benefited from the advantages of ubiquity, interactivity, flexibility of mobile commerce (Tan and Leby Lau, 2016), and the accessibility of customised products and personalised services. "Millennials" or "Generation Y" is the generation born between 1980-2000, they are defined as a generation have the most frequent exposure to technology (Edmunds and Turner 2005), they also are known to operate at "twitch speed" due to possessing high digital literacy and multitasking capabilities, and use social networking sites as mobile devices and constant broadband connectivity allows an "always on" culture (Selwyn et al., 2003). Millennials are arguably the 'digital' generation. They earn averagely less but enjoy spending more, and they are stereotypically addicted to their smartphones (Nieradka 2016). They represent enormous purchasing power, and expect retailers to meet their demands for digital experiences through different distribution channels compared to older generations (Crewe, 2000). Although, there are several studies pertaining to M-shopping adoption in Asia and US (Jang, 2015; Hung et al., 2012), there are only a few studies to date that aim to understand the factors influencing the adoption process of $\mathrm{M}$-shopping and purchase intention in the United Kingdom (Bouwman et al., 2007), particularly, the studies focus on millennials in mobile purchase is limited. Therefore, this research aims to fill in the research gap and explore the factors that influence millennials to use m-commerce when choosing mobile applications / websites to purchase products online, and to understand how the change in new technology has changed their buying behaviour.

\section{LITERATURE REVIEW}

\subsection{Shift to M-shopping}

Aatish (2017) defines m-commerce as "any transaction, involving the transfer of ownership or rights to use goods and services, which is initiated and/or completed by using mobile access to computer-mediated networks with the help of an electronic device". With the number of smartphones and tablets now higher than desktop computers, individuals' method of accessing, using, and sharing information has significantly changed and smartphones have become the predominant driver of growth in m-commerces transactions (Bouwman et al., 2009). In this study, M-shopping is defined as the process of utilising mobile devices; particularly, smartphones in searching, browsing, comparing and purchasing of goods and services (Hillman et al., 2014; Groß, 2014). This definition has been adopted due to the focus of this study on mobile phones rather than tablets. It is reported that in 2017, 95\% of households in the UK have smart phones. This proves the momentous growth of m- Shopping, as in 2000, only $44 \%$ of households owned mobile phones (Statista 2018). This means in 17 years, the ownership of mobiles has doubled and this reflects the explosion of mobile technology in the UK. Buellingen and Woerter (2004) suggested that the key features of M-shopping are comfort, spontaneity and mobility. Additionally Li and Autran (2009) adds that M-shopping also has ubiquity, immediacy, localisation, instant connectivity and proactive functionality. Despite increased functionality, convenience and growth in the use of mobile 


\section{International Journal of Business Management and Economic Review}

Vol. 5, No. 01; 2022

ISSN: 2581-4664

phones, it is still a challenge for retailers to encourage completion of online purchases through a mobile device. Cook and Goette (2006) argue that the technology used for e-commerce may not be compatible with the technology needed to appear on a mobile device. Therefore, it is important for companies to understand the current young consumer behaviours in marketing to meet the needs of the customers which is critical for the successful management and development of Mshopping in the retail industry (Hung et al., 2012).

\subsection{Theoretical foundations}

When discussing the level of acceptance of M-shopping, it is important to review existing theoretical frameworks on factors that influence consumers' perception and attitudes towards the adoption of M-shopping. The Technology Acceptance Model (TAM) is the most cited model that discusses users' acceptance or rejection of a new technology (Davis,1986). TAM proposed that individual's motivation can predict or explain their use of a new technology, therefore consumer's motivation and attitude towards M-shopping impact their intention to adopt it and this is essentially influenced by an external stimulus consisting of the actual system's features and capabilities (Davis et al., 1989). The TAM also suggests that the independent constructs predicting individuals' attitude and intention are perceived usefulness and perceived ease of use. In relation to Mshopping, perceived ease of use and perceived usefulness of a mobile device is very essential because if M-shopping is perceived as being easy to use consumers will generally be more willing to adopt it (Wu and Wang, 2006). Another model relevant in this study is the Technology Readiness Index (TRI). Technology readiness (TR) is referred to as "people's propensity to embrace and use new technologies to accomplish goals in home life and at work", this model was developed to measure people's thoughts and beliefs regarding technology using positive and negative technology related beliefs (Parasuraman, 2000). In management and marketing theory, personality differences are regarded as important in moderating human behaviour, thus this model can help to identify a person's predisposition to new technologies (Kumar and Mukherjee 2015). The TRI model argues that personality can be described as individuals' thoughts and behaviour that are stable over time and relatively consistent across different situations and consists of four traits: Optimism, Innovativeness, Discomfort and Insecurity which measures the thoughts and behaviours of users (Parasuraman, 2000).

\subsection{Hypotheses Development}

\subsubsection{Discomfort and Screen size}

Discomfort can be defined as "a perceived lack of control over technology and a feeling of being overwhelmed by it " (Parasuraman, 2000). Discomfort may be a deterrent to M-shopping adoption due to its linkages to fears and concerns individuals have when considering accepting new technology, thus higher levels of discomfort is likely to lead to lower purchase intention. Discomfort may be caused by many factors such as smaller screen size, lack of consistent Internet access and slow and unwieldy M-shopping sites (Kumar and Mukherjee, 2013). This study will focus on smaller screen size as a deterrent to online shopping due to its ability to create discomfort as reduced screen size is closely related to various user behaviours, including navigation, searching, and browsing (Duchnicky and Kolers 1983). Users may have difficulty reading product details and entering payment information because many sites are still not mobile optimised (Business Insider UK, 2017). A study on the effect of display size on web interaction found that 
International Journal of Business Management and Economic Review

Vol. 5, No. 01; 2022

ISSN: 2581-4664

small screen size reduced user effectiveness by up to $50 \%$ for the tasks being observed (Han and Kwahk 1994), which may explain why M-shopping cart abandonment rates are higher compared to desktop. With such a gap in knowledge, the first two hypothesis were proposed:

Hypothesis 1: Smaller screen sizes significantly and negatively impact consumers discomfort when $\mathrm{m}$-shopping

Hypothesis 2: Discomfort significantly and negatively influence perceive ease of use of Mshopping

\subsubsection{Optimism}

In this study, optimism is referred to as "a positive view of technology and a belief that it offers people increased control, flexibility, and efficiency in their lives (Parasuraman and Colby, 2001) . As optimism generally captures positive feelings about technology, individuals with higher optimism towards technology generally hold positive perceptions towards the adoption of new technology due to the view that it increases their efficiency (Tsikriktsis, 2002).

Therefore, a positive relationship between optimism and perceive ease of use can be assumed because individuals with higher optimism towards technology acceptance would be more likely to embrace M-shopping and find it easy to use. The following hypothesis was proposed:

Hypothesis 3: Higher level of optimism significantly and positively influence consumers perceived ease of use of M-shopping.

\subsubsection{Insecurity}

Insecurity is referred to as a distrust of technology and scepticism about its ability to work properly (Parasuraman and Colby, 2001). Individuals with high levels of insecurity may avoid using a technology due to the fear they associate with it (Kwon and Chidambaram,2000), additionally, insecurity is interlinked with consumer attitude and therefore plays a key role in consumers decision to adopt $\mathrm{M}$-shopping. As a result, security and trust issues are important as M-shopping usually requires customers to provide their financial information, therefore customers may be anxious about the easy access to their personal and financial information if they lose their phone, especially with the introduction of PayPal and Apple Pay ( $\mathrm{Lu}$ and Su, 2009)

The insecurity issues associated with e-business can lead to difficulty in sharing information through electronics (Buchanan et al., 2007) as consumers are worried about how their personal information is going to be used, which can sometimes lead to customers avoiding using website which involves personal information for registration or providing fake information or invalid data (Sheenan and Hoy 1999). It has been discussed by Arvidsson (2014), perceived risk has negative effect on the attitude and adoption of technology-enabled services, consumers are reluctant to adopt the services if there is uncertainty. It can be argued that the increasing level of insecurity is a critical barrier that would discourage young consumers from adopting mobile shopping. Therefore, the following hypothesis is proposed:

Hypothesis 4: Insecurity significantly and negatively influence consumers use of mobile phones for online shopping

\subsubsection{Perceived Ease of Use}

Perceived ease of use relates to the degree a consumer believes using a mobile phone for online shopping will be free from effort. According to Venkatesh et al., (2003), the perceived ease of use 


\section{International Journal of Business Management and Economic Review}

Vol. 5, No. 01; 2022

ISSN: 2581-4664

of a technology significantly determines its acceptance, adoption, and usage behaviour. Many research studies have also indicated that perceived ease of use has a positive impact on the attitude towards usage and behavioural intention (Luan and Teo, 2009; Teo, 2011). Tan and Leby Lau (2016) claimed that majority studies concluded that perceived ease of use has positive effect on the behavioural intention, when users perceive a particular system is easy to use and do not require a lot of effect, they will have a high expectation to adopt the particular system. Furthermore, Davis et al., (1989) found that perceived ease of use is the dominant factor that influence perceived usefulness and may directly influence a consumer's optimism. The following hypothesis is therefore proposed:

Hypothesis 5: Perceived ease of use significantly and positively influence consumers use of mobile phones for online shopping

\subsubsection{Social Media}

With this increasing use in mobile phones, social media are increasingly used in conducting Mshopping (Venkatesh et al., 2003; Ngai and Gunasekaran, 2007). In this study, it is important to consider how social media contributed to the exponential growth of mobile transactions. Considering that teenagers and young adults are addicted to their smartphones, thus, it presents an opportunity for marketers to take this into account in an M-shopping strategy. Social medias platforms encourage customer engagement, therefore is used by many e-commerce websites who are keen to share their products with their target audience (Pelet and Papadopoulou, 2015).

Social media are increasingly replacing traditional media (Yazdanparast et al., 2016), with 95.1\% of social media users accessing their profiles through their mobile phones coupled with the fact that social media marketing is continuously growing with $90 \%$ of large companies having a social media presence (Office of National Statistics, 2017). It is evident that social media has a significant impact on millennials use of mobile phones for online purchases. Therefore, the below hypothesis is proposed:

Hypothesis 6: Social media adverts significantly and positively influence consumers' use of mobile phones for online shopping

\subsubsection{Use of Mobile Phones}

Although, there are some constraints associated with the use of mobile phones for online shopping for example the size of mobile display may be an off-putting factor, it offers advantages such as interactivity, convenience and ability to shop anytime and anywhere (Wang et al., 2015). As a result, the use of mobile phones for purchase and research of products is steadily increasing, especially amongst Millennials (Ho et al., 2007). Shaheen et al., (2019) claimed that mobile devices have become a vital platform for e-retail companies to attract and engage large number of customers. The growth in M-shopping has made retailers realise the importance of mobile optimisation such as instant connectivity, 3D images of products for consumers to experience in online shopping malls or video clips of the product being used to offer ease, increase purchase intention and encourage customers to engage in mobile transactions (Cho, 2007).

Many retailers offer customised information to consumers based on their previous transactions and allow consumers to share information about the products and services they have previously purchased using mobile applications which increases customers' satisfaction and will positively influence mobile transaction intention in M-shopping (Kim et al., 2015). Thus, the below 
International Journal of Business Management and Economic Review

Vol. 5, No. 01; 2022

ISSN: 2581-4664

hypothesis has been proposed.

Hypothesis 7: Consumer use of mobile phones for online shopping significantly and positively influence purchase intention

\subsubsection{Proposed Research framework}

Based on the literatures and theoretical frameworks reviewed, the authors have developed a conceptual model shown in Figure 1. This model is an adaption of the Technology Acceptance Model (TAM) (Davis, 1989) and Technology readiness Index (TRI) (Parasuraman 2000) with factors like perceived ease of use, optimism, insecurity and discomfort included. Additionally, the model incorporates two factors that have received scant attention from previous researches on this topic area, which are the impact of social media and the screen size of mobile devices towards consumer intentions to accept M-shopping.

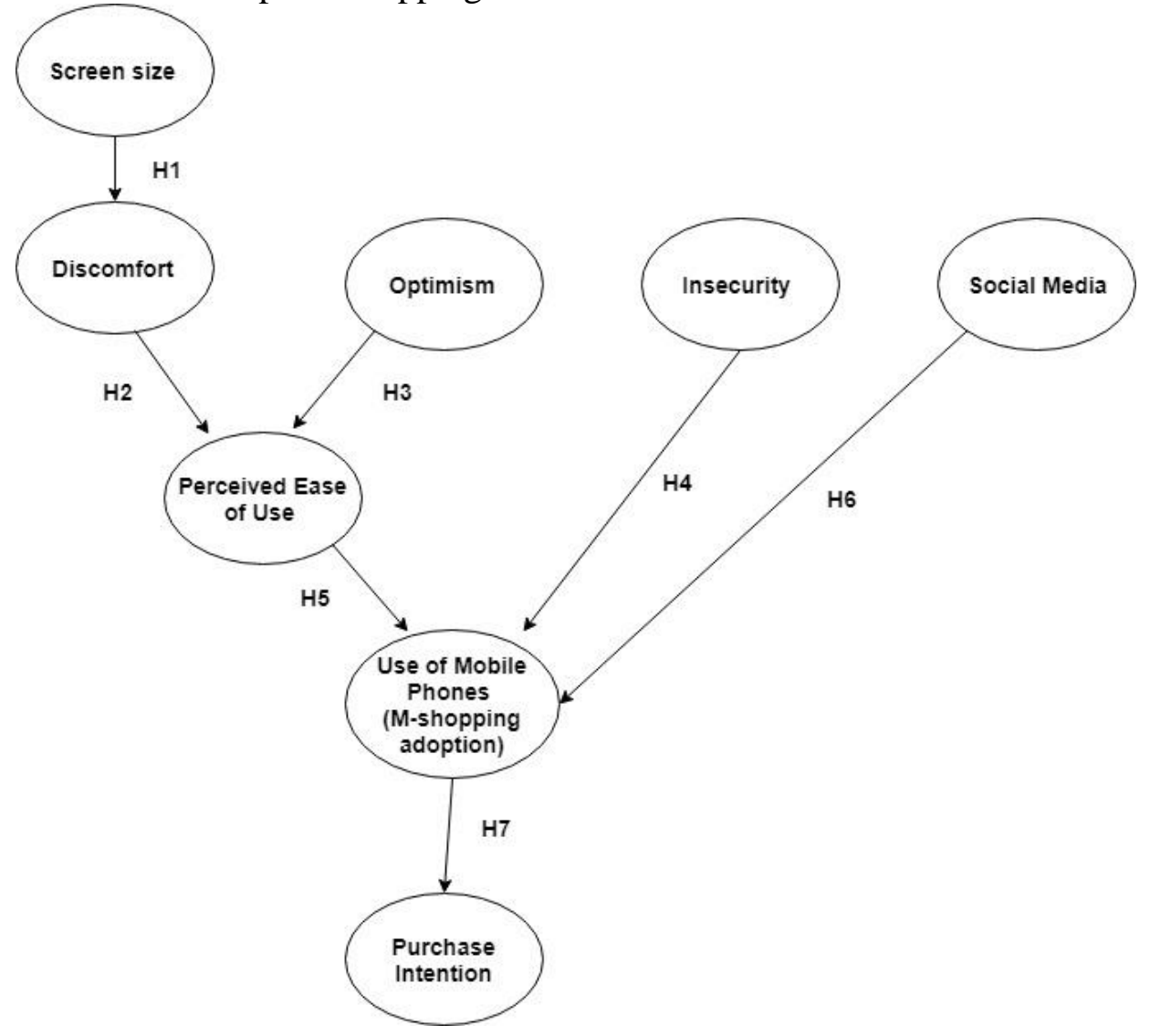

Figure 1: Conceptual research Framework

\section{METHODOLOGY}

\subsection{Sample}

Millennials was targeted in this research because this generation has the most frequent exposure to technology and enormous purchasing power ( Nieradka, 2016). Online Qualtrics survey was distributed across the UK. Respondents were selected based on age segment (18-35 years old). 
Vol. 5, No. 01; 2022

ISSN: 2581-4664

The survey included questions on several factors that potentially impact M-shopping adoption using a 5-point Likert scales and the selected participants were sent a link to access and complete the survey. It was emphasised to the participants that their identity will be kept anonymous which enabled freedom of response and provided valuable and useful results that gave the researcher a great understanding of factors influencing the participants adoption of M-shopping. A total of 213 completed and valid questionnaires were used for data analysis. There are 35\% male and $64 \%$ female, $84 \%$ aged $18-26$ and $16 \%$ aged $27-35$, and finally $50 \%$ of the respondents were students, while $47 \%$ were employed with only $3 \%$ unemployed.

\subsection{Measures}

General demographic information such as gender, age, education level and current employment status were used as control variable in this study. The measures used in this research were adapted from existing literature. Specifically, the scale used to measure perceived ease of use were adopted from Davis (1989) and the scale used to measure optimism, discomfort, insecurity and purchase intention were adopted from Kumar and Mukherjee (2013). To contribute to the empirical research on M-shopping, two additional study variables (social media and screen size) were introduced and new scales were developed to examine the relationship between these factors and M-shopping. Table 1 provides sample scale items for each construct.

\section{Table 1: Sample scale items for constructs}

\begin{tabular}{|l|l|}
\hline Construct & Sample Scale items \\
\hline Screen Size & $\begin{array}{l}\text { - A large screen size makes shopping on my phone easier } \\
\text { - Scren size is an important factor for me when using mobile phones for } \\
\text { online shopping }\end{array}$ \\
\hline - If the screen is small, I find it difficult to use mobile phones for online \\
shopping
\end{tabular}




\begin{tabular}{|c|c|}
\hline & $\begin{array}{l}\text { - I worry that information I send over the internet will be seen by other } \\
\text { people } \\
\text { - I don't feel secure in using mobile phones for online shopping }\end{array}$ \\
\hline $\begin{array}{l}\text { Perceived } \\
\text { ease of use }\end{array}$ & $\begin{array}{l}\text { - I am more likely to purchase using my mobile phone because it is easy } \\
\text { to use } \\
\text { - I find it easy to view the product details on my mobile phone } \\
\text { - I find it easy to enter my payment details when checking out on a } \\
\text { mobile phone } \\
\text { - I believe using my mobile phone for online shopping is free from effort } \\
\text { - I find it easy to use mobile apps for purchases }\end{array}$ \\
\hline Social media & $\begin{array}{l}\text { - I tend to click on these social media adverts with an intention to } \\
\text { purchase } \\
\text { - I actively seek previous consumers recommendations via social media } \\
\text { before I purchase a product online } \\
\text { - Social media reviews and recommendation significantly influences my } \\
\text { intention to purchase }\end{array}$ \\
\hline $\begin{array}{l}\text { Use } \\
\text { mobile } \\
\text { phones }\end{array}$ & $\begin{array}{l}\text { - I find it easy to shop using my mobile phone } \\
\text { - As a millennial, I prefer mobile phones for shopping over other devices, } \\
\text { i.e. laptop/tablets } \\
\text { - I prefer using tablets/laptops for online shopping than mobile phones }\end{array}$ \\
\hline $\begin{array}{l}\text { Intention to } \\
\text { purchase }\end{array}$ & $\begin{array}{l}\text { - I intend to purchase products and services through mobile phones. } \\
\text { - My likelihood to purchase products using mobile phones is high } \\
\text { - I intend to purchase the products I see in social media adverts }\end{array}$ \\
\hline
\end{tabular}

\section{DATA ANALYSIS AND RESULTS}

The quantitative data collected from the online survey was analysed using SPSS Statistics Software. Furthermore, Structural Equation Modelling using AMOS graphics was used to identify the effect and relationship of independent variables on their dependent variables (Anderson and Gerbing, 1988).

\subsection{Reliability, Validity and Preliminary Analysi $s$}

Reliability and validity of a research is what determines the quality of that research (Saunders $e t$ al., 2012). SPSS Cronbach alpha was utilised in identifying the reliability levels while factor analysis was conducted to measure the validity of each variable. This enabled the establishment of correct operational measures for the concepts being studied (Yin, 2003) in the final survey administered. Factor analysis is used to test the validity of a construct, it is important that all 3-5 questions in each scale represents the one underlying construct and the overall validity value should be over 50\% (Bornstedt, 1977; Rattray and Jones, 2007).

Results from the validity and reliability tests prompted several changes to improve the statistical stability of the survey. Two constructs (discomfort and perceived ease of use) had the required 
reliability and validity of at least 0.7 and 50\% respectively (Nunnaly 1978; Bornstedt, 1977; Rattray and Jones, 2007) and could stand as independent constructs, therefore, no questions were deleted from these constructs. However, the six remaining factors had problems with the reliability or validity which lead to a decision being made to delete 12 questions to improve the overall reliability and validity. The factor analysis revealed that all factors were above 50\% suggesting adequate item validity (Hair et al., 2010). The Cronbach's alpha scores ranged between 0.662 and 0.855 , indicating adequate convergence. Although, purchase intention and screen size did not attained the recommended reliability of 0.7 , a realibility value of 0.6 is deemed acceptable for exploratory studies (Hair et al., 2006).

Empirically and theoretically, the factor analysis and Cronbach alpha and both the exploratory and confirmatory factor analyses of the data set suggest that the eight-factor structure is the most appropriate as it provides stable and generalisable measures on intention to adopt M-shopping, as well as is consistent with the theoretical framework supporting this study. Table 2 provides the questions within each construct from the validity and reliability analyses.

Table 2: Summary of constructs and questions

\begin{tabular}{|c|c|c|c|c|}
\hline Construct & $\begin{array}{l}\text { Number } \\
\text { of Items }\end{array}$ & Items & $\begin{array}{c}\text { Cronbach } \\
\text { Alpha }\end{array}$ & Uni-dimentionality \\
\hline $\begin{array}{l}\text { Discomfort } \\
\text { (DISQ) }\end{array}$ & 4 & $\begin{array}{l}\text { DISQ1, DISQ2, } \\
\text { DISQ3, DISQ4 }\end{array}$ & 0.843 & 68.117 \\
\hline $\begin{array}{l}\text { Screen size } \\
\text { (SS) }\end{array}$ & 3 & $\begin{array}{c}\text { SSQ1, SSQ3 } \\
\text { SSQ5 }\end{array}$ & 0.662 & 59.947 \\
\hline $\begin{array}{l}\text { Optimism } \\
\text { (OPT) }\end{array}$ & 3 & $\begin{array}{c}\text { OPTQ3, OPTQ4 } \\
\text { OPTQ5 }\end{array}$ & & \\
\hline $\begin{array}{l}\text { Insecurity } \\
\text { (INS) }\end{array}$ & 4 & $\begin{array}{c}\text { INSQ1, } \\
\text { INSQ2,INSQ3, } \\
\text { INSQ4 }\end{array}$ & 0.855 & 69.870 \\
\hline $\begin{array}{l}\text { Social Media } \\
\text { (SM) }\end{array}$ & 3 & $\begin{array}{c}\text { SMQ3,SMQ4 } \\
\text { SMQ5 }\end{array}$ & 0.712 & 63.682 \\
\hline $\begin{array}{l}\text { Perceived } \\
\text { Ease of Use } \\
\text { (PEU) }\end{array}$ & 5 & $\begin{array}{c}\text { PEUQ1,PEUQ2, } \\
\text { PEUQ3,PEUQ4, } \\
\text { PEUQ5 }\end{array}$ & 0.852 & 62.943 \\
\hline $\begin{array}{l}\text { Use of Mobile } \\
\text { Phone (MS) }\end{array}$ & 3 & $\begin{array}{c}\text { MSQ2,MSQ3, } \\
\text { MSQ4 }\end{array}$ & 0.834 & 75.465 \\
\hline $\begin{array}{l}\text { Purchase } \\
\text { Intention (PI) }\end{array}$ & 3 & $\begin{array}{c}\text { PIQ1,PIQ2, } \\
\text { PIQ3 }\end{array}$ & 0.671 & 64.083 \\
\hline
\end{tabular}

\subsection{Measurement Model}

Exploratory Factor Analysis (EFA) was conducted to identify how well the measurement items load on a certain construct and all the items loaded well onto their respective constructs. The EFA alongside the factor analysis also confirmed uni-dimensionality suggesting that the measured variables were explained by only one underlying construct which is important as more than two constructs are involved in this study (Hair et al., 2010).

A measurement model using confirmatory factor analysis (CFA) was also tested to assess the 
Vol. 5, No. 01; 2022

ISSN: 2581-4664

overall model fit, the goodness-of-fit indices was used to ensure that the theoretical model fits the data (Schumacker and Lomax, 1996). The CFA identified that the screen size and social media factors hindered the overall fit of the model. Therefore, a CFA measurement model removing the two factors was tested and the six remining constructs with 22 measures showed an acceptable model fit $(\mathrm{x} 2=384.608, \mathrm{x} 2 / \mathrm{df}=1.972, \mathrm{p}=0.000$, Goodness-of-Fit index $(\mathrm{GFI})=0.862$, Normed Fit index $(\mathrm{NFI})=0.871$, Tucker-Lewis index $(\mathrm{TLI})=0.918$, Comparative Fit index $(\mathrm{CFI})=0.931$, Root Mean Square Error of Approximation (RMSEA) $=0.068$ ). The chi-square is very sensitive to sample sizes (Bagozzi and Yi, 2012), therefore is not relied upon as a basis for acceptance or rejection (Schlermelleh-Engel et al., 2003, Vandenberg 2006) and all the other indices are within their acceptable ranges in support of satisfactory model fit (Hair et al., 2010).

Furthermore, Structural Equation Modelling (SEM) was conducted using AMOS (Figure 2) to examine the effects of the proposed variables (discomfort, optimism, insecurity, perceived ease of use and use of mobile phone) on Millennials M-shopping purchase intentions. SEM is a useful tool used especially in business research to assess variable relationships that are linear (Babin et al., 2008), therefore SEM is very beneficial for analysing the data in this study due to its potential for theory development and testing as well as validating constructs (Anderson and Gerbing, 1988). It can also provide overall tests of model fit through examination of multiple interrelated relationships in a single model, thereby reducing standard errors (Hair et al., 2010; Iacobucci et al., 2007). Finally, using SEM allows the researchers to simultaneously compare regression coefficients, $t$ values, $p$ values and variances. 
Vol. 5, No. 01; 2022

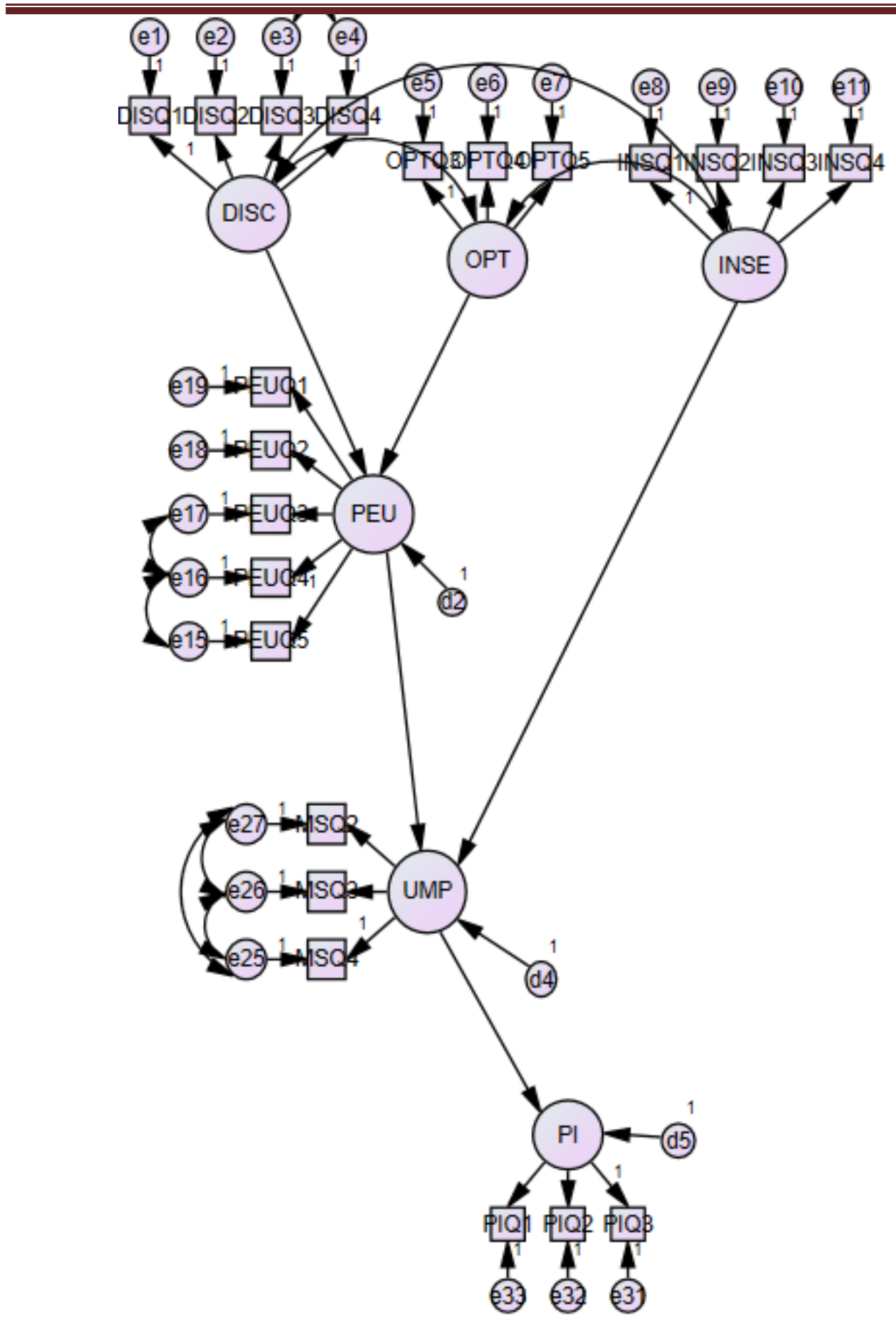

Figure 2: Model displaying by using AMOS

Figure 3 below outlines the structural equation model within this research and presents the $R$ square value, $t$ and $p$ value and the beta coefficient for each path of the theoretical model. Two constructs, screen size and social media have been removed from the model since they present an insignificant and weak relationship with the adoption of M-shopping. 
International Journal of Business Management and Economic Review

Vol. 5, No. 01; 2022

ISSN: 2581-4664

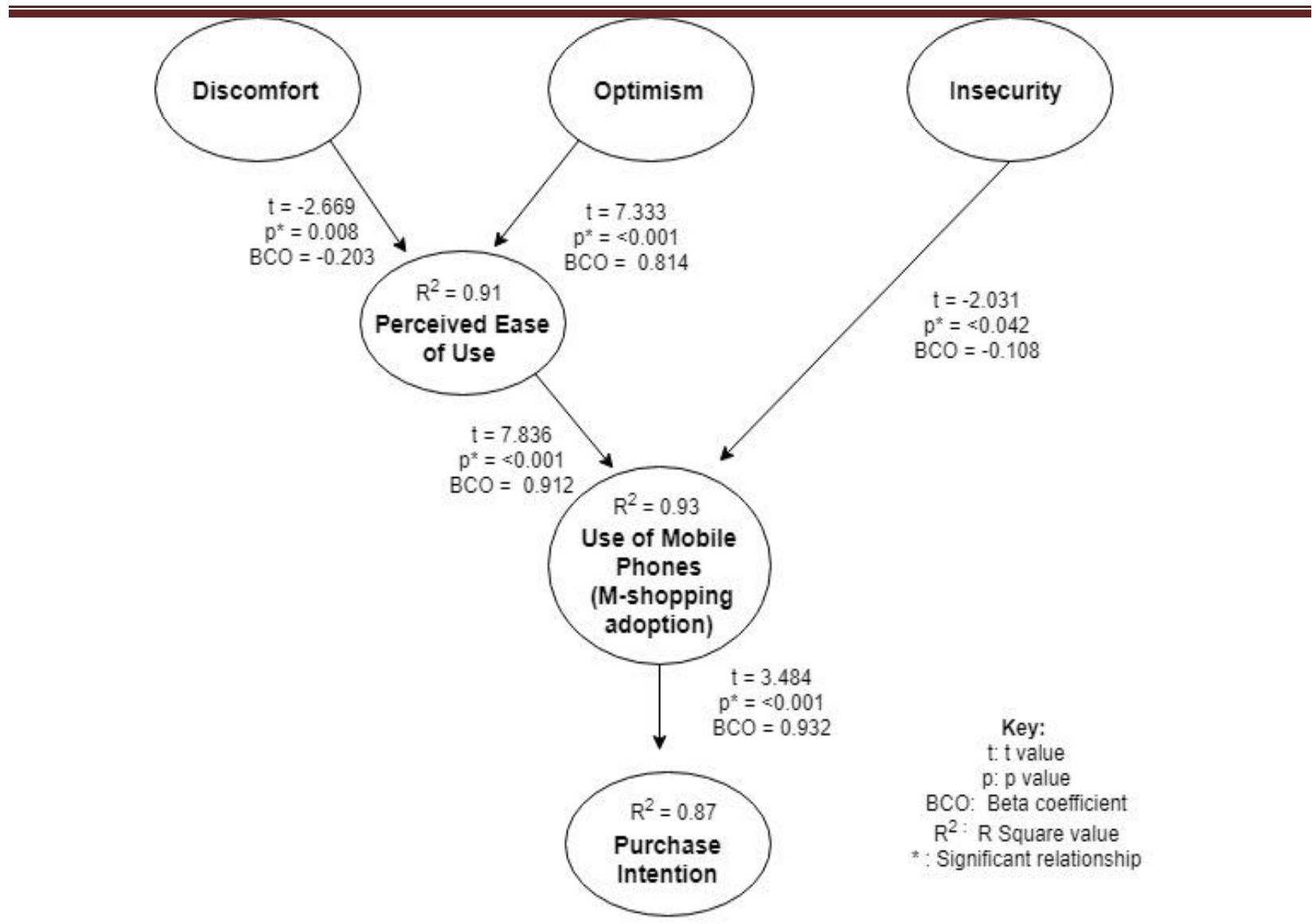

Figure 3: Tested results

Figure 3 shows that the results from the data analysis conform to the model fit criteria and have a significant relationship with all the remaining paths. Additionally, discomfort, optimism and insecurity are the independent variables that exercise significant influence on use of mobile phones for online shopping and purchase intention. The $p$ values show level of significance $<0.001$ and $<0.05$, which meets the acceptable level of $\mathrm{p}$ values which should be at least $<0.05$ (Saunders $e t$ al., 2012). The $\mathrm{p}$ values mean that there is a confidence level of $95 \%$ and $99 \%$ in the relationship between variables, therefore all factors in the model are statistically significant.

The Beta coefficient assesses the strength of relationship between any two factors, the coefficient ranges from perfectly negative correlation (a score of -1) to perfectly positive correlation (a score of 1) with an in-between score of 0 representing no correlation between the dependent and independent variables (Saunders et al., 2012). Based on the results highlighted in figure 3, this has been achieved with beta coefficient scores of -0.203 and -0.108 for discomfort and insecurity which is expected as these factors should represent a negative correlation. Optimism, perceived ease of use and use of mobile phones have beta coefficient ranging from 0.814 to 0.932 suggesting the relationships between factors are significant and almost perfectly positive. The $\mathrm{R}$ square value identified to what extent independent variables can cause changes in dependent variables (Saunders et al., 2012) and follows a rating scale ranging from -1 to 1 , like the beta coefficient. As 
International Journal of Business Management and Economic Review

Vol. 5, No. 01; 2022

ISSN: 2581-4664

seen from figure 2 , the $\mathrm{R}$ square values for the factors in the model ranged from 0.87 to 0.93 which means there is little scope of unknown variables influencing the dependent variable (only $7 \%$ to $13 \%)$.

\subsection{Hypothesis testing and Discussions}

The findings of this study highlight that majority of the proposed drivers do influence Millennials' use of mobile phone for online shopping and their purchase intention, however, some hypothesis were not supported. Table 3 showed the outcomes of the hypothesis testing of this research.

Table 3: Summary of hypothesis testing

\begin{tabular}{|c|c|c|c|}
\hline Hypothesis & Structural Paths & $\begin{array}{l}\text { Standardised } \\
\text { Estimated }\end{array}$ & $\begin{array}{l}\text { Hypothesis } \\
\text { Acceptance }\end{array}$ \\
\hline H1 & Screen size $\rightarrow$ Discomfort & $\mathrm{ns}$ & Rejected \\
\hline $\mathrm{H} 2$ & Discomfort $\rightarrow$ Perceived Ease of Use & -0.203 & Accepted \\
\hline H3 & Optimism $\rightarrow$ Perceived Ease of Use & 0.814 & Accepted \\
\hline H4 & Insecurity $\rightarrow$ Use of Mobile Phone & -0.108 & Accepted \\
\hline H5 & $\begin{array}{l}\text { Perceived Ease of Use } \rightarrow \text { Use of } \\
\text { Mobile Phones }\end{array}$ & 0.912 & Accepted \\
\hline H6 & Social Media $\rightarrow$ Use of Mobile Phone & ns & Rejected \\
\hline H7 & $\begin{array}{l}\text { Use of Mobile Phone } \rightarrow \text { Purchase } \\
\text { Intention }\end{array}$ & 0.932 & Accepted \\
\hline
\end{tabular}

Significant at $p<.001 ; 0$. s. Non-Significant

Hypothesis 1 stated that smaller screen sizes significantly and negatively impact consumers' discomfort when M-shopping. This hypothesis was not supported by the data collected and due to a significance level (p) of 0.207 and a beta coefficient $(\beta)$ of -0.968 . The outcome was surprised as previous research suggests a relationship between these two factors (Duchnicky and Kolers 1983, Dillon et al., 1990). This difference may be because smartphones are the dominant mobile devices of today, specifically among Millennials are more likely to use smartphones for most "mobile" activities despite small screen sizes and keyboards, Therefore, due to the dependency on mobile phone, screen size is becoming less of deterrent as the amount of time that people spend using smartphones is creating a sense of comfort that seems to trump concerns about screen size (GFK Media, 2012). In addition, Smartphones are also becoming larger and more viewing oriented, therefore decreasing the level of discomfort compared to earlier years (Bingham, 2017). Developments such as responsive web design where the website is automatically redesigned to fit the screen of the device used has also reduced the negative impact of screen size as users do not need to manually zoom and adjust the screen fit on their devices or access a separate mobile compatible website to shop easily (Coremedia 2013).

It was proposed that discomfort significantly and negatively influence perceive ease of use of M- 


\section{International Journal of Business Management and Economic Review}

Vol. 5, No. 01; 2022

ISSN: 2581-4664

shopping. Hypothesis 2 can be accepted as the $\mathrm{p}$ of 0.008 shows optimism significantly influences PEU. The beta coefficient of -0.203 also suggests a negative causal relationship between the two factors showing as discomfort increases, consumers are less likely to find M-shopping easy to use. Discomfort plays an important contribution to the perceived ease of use of mobile phones for online shopping. This negative causal relationship is supported by precious research that identified that individuals with high level of discomfort are more speculative and uncomfortable with use of new technology, therefore acceptance of M-shopping might will be a struggle for them and thus the perceived ease of use of m-shopping will be low for these individuals (Ha and Stoel, 2009).

This study hypothesized a positive link between optimism and perceived ease of use of Mshopping is also accepted with the data collated. Hypothesis 3 indicated the relationship between the two factors is significant with the $\mathrm{p}$ value at $<0.001$ and the beta coefficient of 0.814 . This suggests young consumers are likely to find $\mathrm{M}$-shopping easier to use as their optimism increases. It is not surprising to see the positive causal relationship between optimism and perceived ease of use, because as discovered from the literature review and proven by the data collated, having "a positive view of technology will generally offer individuals increased control, flexibility, and efficiency in their lives" (Parasuraman, 2000). Research shows that personality traits are important in influencing perception and acceptance of technology, thus individuals with high optimism on the TRI feel more comfortable and more accepting of new technology (Parasuraman and Colby, 2001). Millennials often have an optimistic view of technology and enjoy interacting with new technologies because they find them entertaining (Karahanna et al., 1999), therefore they embrace M-shopping and perceive it to be easy to use in their day-to-day life.

In this study, it assumed that insecurity significantly and negatively influence the use of mobile phones for online shopping, thus hypothesis 4 can be accepted. The $p$ value of $<0.001$ and a beta coefficient of -0.108 confirms that these factors do have a strong negative relationship. Thus, consumers with insecurity towards $\mathrm{m}$-shopping will be less likely to adopt it. This finding was supported by previous studies because insecurity or apprehensiveness leads to avoiding a particular technology because of the innate fear associated with technology in general (Kwon and Chidambaram, 2000). Therefore, individuals with high levels of insecurity may avoid M-shopping, especially since it's a relatively recent phenomenon and has several factors that makes consumers anxious such as poor connectivity, fear of lack of control over personal information, especially if the device is lost or stolen ( $\mathrm{Lu}$ and $\mathrm{Su}, 2009$ ). As security and privacy issues are a central axis for the adoption of M-shopping, consumers worry about companies using their voluntary information disclosure to improve transparency and build a relationship as well as driving traffic which consumers are starting to see this as being intrusive (Lamarre et al., 2012). This increases the level of insecurity amongst consumers therefore sustaining insecurity as a deterrent to the adoption of M-shopping.

The outcome of Hypothesis 5 proved that the perceived ease of use significantly and positively influence the use of mobile phones for online shopping. This relationship has a strong significance level of $<0.001$ and the beta coefficient of 0.912 means that the hypothesis can be accepted. Therefore, as perceived ease of use increases amongst Millennials, so will the adoption of Mshopping. Previous studies indicated that perceived ease of use influences the actual use of technology (Parasuraman, 2000) which explains the relationship between the two constructs. High perceived ease of use reflects a positive relationship on M-shopping while low perceived ease of 


\section{International Journal of Business Management and Economic Review}

Vol. 5, No. 01; 2022

ISSN: 2581-4664

use indirectly influenced by insecurity and discomfort will have a direct impact of discouraging M-shopping (Venkatesh, 1999). Millennials believe that technology is free from effort, and as Mshopping is becoming easier and intuitive, there is an increasing positive perception toward it (Davis, 1989), thus increasing its adoption and intention to purchase via mobile phones.

This study originally proposed that social media adverts significantly and positively influence consumers' use of mobile phones for online shopping, however, Hypothesis 6 was rejected due to an insignificant $\mathrm{p}$ of 0.341 and a beta coefficient of -0.059. Meaning, increase in social media adverts does not necessarily mean an increase in rate of Millennials who use their mobile phones for shopping. The outcome was surprising as the hypothesis was supported by previous studies which indicate that the continuing evolution of smartphones favours mobile commerce primarily due to social media being increasingly used in conducting M-shopping (Venkatesh et al., 2003; Ngai and Gunasekaran, 2007). This incongruence can be due to minimal studies on this area causing the author to develop new questions which may have been misunderstood by the survey respondents. In addition, individuals are heavily reliant on mobile phones, using it 150 times a day on average (Leslie, 2016) and mobile apps such as social media account for $89 \%$ of consumers' media time (Chaffey, 2016). This has contributed to the increase in research on the negative sides of mobile technology and social media, therefore increasing awareness on the negative influence on the structure of individuals' personal, social and professional lives (Holland and Bardoel, 2016; Rennecker and Godwin, 2005). Research has recognised psychological damages such as depression, sleep disorder, declined academic performance and stress, quality social and individual relationships and satisfaction with life (Samaha and Hawi, 2016), which has contributed to individuals actively working towards the amount of time they spend on their phone, especially social media which may explain the insignificant relationship between social media and Mshopping.

The findings indicated that consumer use of mobile phones significantly and positively influence intention to purchase using mobile phones. Hypothesis 7 is accepted as the p value of $<0.001$ suggests a significant relationship between the two factors. This relationship also has very strong beta coefficient at 0.932 suggesting that use of mobile phones can equate for $93 \%$ of variances within purchase intention. Additionally, as the adoption of M-shopping increases, Millennials intention to purchase using mobile phones will also increase. There is an increase use of mobile phones for day to day activities and the growing choices of apps and developments that enhance m-shopping through improved daily shopping tools and banking transactions (Jang, 2015). The advantages of $\mathrm{M}$-shopping such as time and space benefits have created an important commercial channel for companies and consumers, thus, shoppers' purchase intention through mobile is increasing due to a more positive attitudinal disposition towards M-shopping, which is an outcome of their overall satisfaction with M-shopping encounters (Shankar et al., 2003).

\section{CONCLUSION}

\subsection{Limitations and future research}

Some limitations of this study should be highlighted. First, this is a country-specific study, future studies should include cross-country comparison. Second, data were obtained only from UK millennials 18-35 years of age, who were unable to represent the whole population due to the size constraints, and therefore a generalisation cannot be applied to the study, future research can be appreciated across different occupation, age and income groups. This study and many other studies 


\section{International Journal of Business Management and Economic Review}

Vol. 5, No. 01; 2022

ISSN: 2581-4664

reviewed focused on consumers' adoption of M-shopping, thus another opportunity for future research is to explore M-shopping adoption from retailer's perspective. More studies on retailers' willingness to adopt $\mathrm{M}$-shopping systems or their contributions to encouraging consumers to adopt M-shopping can help to fill an apparent gap in the current literature.

\subsection{Research implications}

A literature gap observed between prevailing studies and modern statistics shows a need for contemporary research concerning the acceptance of mobile shopping amongst consumers. Due to the contemporary nature of this research problem and the rapid development of technology, it is important to explore how mobile shopping impacts consumers and how it has shaped our shopping experiences and perceptions in this digital age. Existing studies fail to exclusively address the implications of factors such as screen size and social media on mobile shopping adoption and purchase intention. Thus, the M-shopping phenomenon calls for a great deal of innovative research which this study aims to deliver by addressing the signified research gaps and adding to existing literature within the subject area. This research filled the gap by investigating the influencing factors in addition to several constructs from the Technology Acceptance Model (TAM) (Davis, 1986) and Technology Readiness Index (TRI) (Parasuraman 2000) to explore the UK Millennials' intention to use mobile phones for purchases. Although the data collected showed an insignificant relationship, existing research highlights that social media marketing is key to M-shopping adoption, the findings of this research contributed the academic literature that there is a significant influence of discomfort and optimism on perceived ease of use of M-shopping and a negative causal relationship between insecurity and use of mobile phones for online shopping. The study also confirmed that perceived ease of use contributes to the use of mobile phones for shopping which impacts the purchase intention of consumers.

The adoption of M-shopping is an important business issue which is highly beneficial to both consumers and companies. M-shopping offers ease and convenience to consumers and enables them to shop more efficiently and it can result in stronger financial success of an organisation through its ability to increase the likelihood of purchases as consumers are able to shop on the go at any time. The anticipated outcomes of this study benefit organisations as they can identify ways to encourage M-shopping adoption among consumers in order to improve the purchase intention of consumers and generate more sales revenue. There is a significant number of Millennials utilise their mobile phones for pre-purchasing activities which enhances the probability of buying through the mobile phones, thus retailers need constantly improve the mobile compatibility of their websites and mobile apps to increases acceptance of M-shopping. The increasing pleasantness of the websites or mobile app encourages consumers to spend more time on them, thus increasing purchase intention (Menon and Kahn, 2002). The findings of this study can help retailers have a better understanding of Millennials' M-shopping behaviours, knowing factors important to users is essential in creating a more compelling M-shopping experience, thereby potentially boosting profits, additionally, the outcomes of this study provided retailers with strategic tools to improve consumers satisfaction while shopping on mobile phones, for example, this research highlights that discomfort through screen size, connection speed, inaccessible design has a significant impact on user experience and the adoption of M-shopping, there are a number of ways companies can reduce the discomfort consumers face such as ensuring their websites are mobile compatible with good and trustworthy user interface, easy navigation and clear visibility of products and product information. Companies could also adopt apps in addition to their websites to offer consumers 


\section{International Journal of Business Management and Economic Review}

Vol. 5, No. 01; 2022

ISSN: 2581-4664

more payment and access options, Mobile compatible websites and apps makes it easy for consumers to shop effectively and efficiently as completing their online purchases will require less time and effort.

\section{REFERENCES}

Aatish, C., (2017), Automating the process from e-commerce to m-commerce [online]. (Issue 1), $1-5$

Anderson, J.C., Gerbing, D.W.,(1988), "Structural equation modelling in practice: A review and recommended two---step approach", Psychological Bulletin, 103(3), 411---423.

Arvidsson, N. (2014), "Consumer attitudes on mobile payment services - results from a proof of concept test”, International Journal of Bank Marketing, Vol. 32 No. 2, pp. 150-170.

Babin, B.J. , Hair, J.F. and Boles, J.S. (2008), "Publishing research in marketing journals using structural equation modeling", Journal of Marketing Theory and Practice, Vol. 16 No. 4, p.

Bagozzi, R.P., Yi, Y. (2012), "Specification, evaluation, and interpretation of structural equation models", Journal of the Acad. Mark. Sci. 40, 8-34

Bingham, J., 2017. Are mobiles changing how we shop? [Online] Telegraph.co.uk. Available at: http://www.telegraph.co.uk/news/shopping-and-consumer-news/12172230/Are-mobileschanging-how-we-shop.html [Accessed 5 Nov. 2017].

Bolton, N. R. and Parasuraman, H. A. and Migchels, N. and Kabadayi, S. and Gruber, T. and Loureiro, K. Y. and Solnet, D. (2013), "Understanding Generation Y and their use of social media: a review and research agenda", Journal of Service Management. (Issue 3), 245-267

Bornstedt, G.W., (1977), Reliability and Validity in Attitude Measurement. In: G.F. Summers (Ed.), Attitude Measurement (pp. 80-99). Kershaw Publishing

Company: London.

Bouwman, H., Carlsson, C., Walden, P. and Molina-Castillo, F. (2009), " Reconsidering the actual and future use of mobile services", Information Systems and e-Business Management, Vol. 7 No. 3, pp. 301-317.

Buellingen, F. and Woerter, M. ( 2004), “ Development perspectives, firm strategies and applications in mobile commerce". Journal of Business Research . (Issue 12), 1402-1408

Buchanan, T., Paine, C., Joinson, A.N. and Reips, U.D., (2007), "Development of measures of online privacy concern and protection for use on the internet", Journal of the American Society for Information Science and Technology, vol. 58, pp.157-165, 2007.

Business Insider UK. (2017). Mobile sales drive unexpected UK e-commerce growth. [Online]. Available at: http://uk.businessinsider.com/mobile-sales-drive-unexpected-uk-e-commercegrowth-2017-1 [Accessed 5 Nov. 2019].

Chaffey, D., (2016). Mobile marketing statistics compilation. Available at https://www.smartinsights.com/mobile-marketing/mobile-marketing-analytics/mobile-

marketing-statistics/. [Accessed 15 April 2018].

Cho, H. ( 2007), "The Effect of Trust and Distrust on the Purchase Intention at Internet Shopping Mall”, Journal of Commodity Science and Technology, 25(2), 85-95

Cook, A. and Goette, T. (2006), "Mobile Electronic Commerce: What Is It? Who Uses It? And Why Use It?", Communications of the IIMA. (Issue 4), 49-58

Coremedia, H., (2013). Are you ready for the mobile web?: A guide for media companies. Coremedia.com pp. 2-5. Available at: http://www.coremedia.com/linkableblob/view//31820/data/2/-/_gpwp7t/-/Responsive-Web-Design-BSG-A4-.pdf [Accessed 25 May 2018]. 


\section{International Journal of Business Management and Economic Review}

Vol. 5, No. 01; 2022

ISSN: 2581-4664

Crewe, L., (2000), "Geographies of retailing and consumption", Progress in Human Geography. (Issue 2), 275-290

Davis, F.D., (1989), "Perceived usefulness, perceived ease of use, and user acceptance of information technology", MIS Quarterly, 13(3), 319---340.

Davis, F.D., Bagozzi, R.P., \& Warshaw, P.R. (1989), "User acceptance of computer technology: a comparison of two theoretical models", Management Science, 35(8), 982-1003.

Dillon, A., McKnight, C. and Richardson, J. (1990), "The effects of display size and text splitting on reading lengthy text from screen", Behaviour \& Information Technology, Vol. 9 No. 3 , pp. 215-27.

Duchnicky, R. And Kolers, P. (1983), " Readability of text scrolled on visual display terminals as a function of window size". Human Factors, 25, 683 - 692

Edmunds, J. and Turner, B.S. (2005), "Global Generations: Social Change in the Twentieth Century", British Journal of Sociology, Vol. 56, No. 4: 559-78

GFK Media, (2012), Generations X, Y Adopt Smartphones as Media Hubs; Tablets Dominate on Long Viewing Sessions.

Grabham, J. and Jones, R., History of the iPhone 2007-2017: the journey to iPhone X [online]. Bath: T3. Available form: https://www.t3.com/features/a-brief-history-of-the-iphone [Accessed 30 October 2019]

Groß, M., (2015), "M-shopping: a classification framework and literature review", International Journal of Retail \& Distribution Management, Vol. 43 No. 3, pp. 221-241.

Ha, S. and Stoel, L. (2009), "Consumer E-Shopping Acceptance: Antecedents in a Technology Acceptance Model". Journal of Business Research, 62, 565-571.

Hair, J., Black, W., Babin, B., Anderson, R., \& Tatham, R. (2006), Multivariate data analysis (6th ed.) Uppersaddle River, N.J.: Pearson Prentice Hall.

Han, S. And Kwahk, J. (1994), "Design of a menu for small displays presenting a single item at a time". Proceedings of the Human Factors and Ergonomics Society 38th Annual Meeting, pp. 360 -364 .

Hillman, S., Neustaedter, C., Bowes, J. and Antle, A. (2012), "Soft trust and m-shopping shopping behaviours". 14th International Conference on Human-Computer Interaction with Mobile Devices and Services, ACM, September, pp. 113-122.

Ho, S. C., Kauffman, R. J., and Liang, T. P. (2007), "A Growth Theory Perspective on B2C ecommerce Growth in Europe: An Exploratory Study", Electronic Commerce Research and Applications, 6, pp. 237-259.

Holland, P., and Bardoel, A. (2016), "The impact of technology on work in the twenty-first century: Exploring the smart and the dark side", The International Journal of Human Resource Management, 27(21), 2579-2581. doi:10.1080/09585192.2016.1238126

Hung, M.C., Yang, S.T. and Hsieh, T.C. (2012), " An examination of the determinants of mshopping continuance", International Journal of Electronic Business Management, Vol. 10 No. 1, p. 29.

Iacobucci, D., Saldanha, N. and Deng, X. (2007), “A meditation on mediation: evidence that structural equations models perform better than regressions", Journal of Consumer Psychology, Vol. 17 No. 2, pp. 139-153.

Imrg.org. (2017). Over half of online sales now made through mobile devices. [Online] Available at: https://www.imrg.org/media-and-comment/press-releases/over-half-of-online-sales-now- 


\section{International Journal of Business Management and Economic Review}

Vol. 5, No. 01; 2022

ISSN: 2581-4664

made-through-mobile-devices/ [Accessed 5 Nov. 2018].

Jang, Y.G., (2015), "Effects of M-shopping Characteristics on Purchase Intention in a Smart Media Environment", Journal of Marketing Thought, Vol. 2, No. 2, 60 - 72, DOI: 10.15577/jmt.2015.02.02.7

Karam, L., (2018), M-commerce's Increased Importance [online]. Barcelona: Apiumhub. Available from: https://apiumhub.com/tech-blog-barcelona/m-commerce-growth/ [Accessed 30 October 2019]

Karahanna, E., Straub, D., \& Chervany, N. (1999). "Information Technology Acceptance across Time: A Cross-Sectional Comparison of Pre-Adoption and Post-Adoption Beliefs.", MIS Quarterly, 23, 183-213.

Kumar, A; Mukherjee, A.( 2013), "Shop While You Talk: Determinants of Purchase Intentions Through A Mobile Devic", International Journal of Mobile Marketing, Vol. 8, No. 1 pp.23-37.

Kwon, H., \& Chidambaram, L. (2000). A test of the Technology Acceptance Model: The Case of Cellular Telephone Adoption. In: Proceedings of HICSS-34, Hawaii, 2000.

Lamarre, A., Galarneau, S. And Boeck, H., (2012), 'Mobile Marketing and Consumer Behaviour Current Research Trends'. International Journal Of Latest Trends In Computing, Vol. 3, No. 1, Pp.1-9.

Leslie, I., (2016), The scientists who make apps addictive. The Economist. Retrieved from: https://www.1843magazine.com/features/the-scientists-who-make-appsaddictive. [Accessed 15 April 2020].

Li, X. and Autran, G., (2009), Implementing an Mobile Agent Platform for M-commerce, 33rd Annual IEEE International Computer Software and Applications Conference, 2009, p. 50-45.

Lu, H.P. and Su, P.Y.J. (2009), "Factors affecting purchase intention on mobile shopping web sites", Internet Research, Vol. 19 No. 4, pp. 442-58.

Menon, S., Kahn, B. (2002), "Cross-category effects of induced arousal and pleasure on the Internet shopping experience", Journal of Retailing, 78(1), 31-40.

Milnes, H. ( 2015), Christmas in July: the 2015 online holiday shopping forecast in 5 charts". Available at: http://digiday.com/brands/christmas-july-2015-holiday-shopping-forecast-5-charts/. [Accessed 15 April 2018]

Nieradka, P.( 2016), The use of mobile applications in the group of generation Y. In: Managing Innovation and Diversity in Knowledge Society Through Turbulent Time., eds. Joint International Conference 2016, Romania 25-27 May 2016.

Ngai, E. W. T., \& Gunasekaran, A. (2007), "Mobile commerce: strategies, technologies, and applications", Decision Support Systems, 43(1), 1-2.

Nunnally, J. C. (1978), Assessment of Reliability. In: Psychometric Theory (2nd ed.). New York: McGraw-Hill, pp 245-246

Office of National Statistics, (2017), [online]. www.ons.gov.uk, [Accessed 3 Jun 2020].

Pahwa, A., (2018), What is M-commerce | The rise of Mobile Commerce [online]. India: Feedough. Available from: https://www.feedough.com/m-commerce-rise-mobile-commerce/ [Accessed 30 October 2019]

Parasuraman, A. and Colby, C.L. (2001) Techno-Ready Marketing: How and Why Your Customers Adopt Technology. The Free Press, New York.

Parasuraman, A. (2000). "Technology Readiness Index (TRI) a multiple-item scale to measure readiness to embrace new technologies". Journal of Service Research. 2 (4): 307-320 


\section{International Journal of Business Management and Economic Review}

Vol. 5, No. 01; 2022

ISSN: 2581-4664

Pelet, J.E., Papadopoulou, P. (2015), "Social media and m-shopping", Internet Marketing and Advertising, Vol. 9, No. 1, 2015

Rattray, J. and Jones, M.C. (2007), "Essential Elements of Questionnaire Design and Development". Journal of Clinical Nursing, 16, 234-243.

Rennecker, J. \& Godwin, L. (2005), "Delays and interruptions: A self-perpetuating paradox of communication technology use", Information and Organization, 15, 247-266.

Samaha, M., \& Hawi, N. S. (2016), "Relationships among smartphone addiction, stress, academic performance, and satisfaction with life", Computers in Human Behavior, 57, 321-325.

Saunders, M., Lewis, P. and Thornhill, A. (2012), Research Methods for Business Students. Pearson Education Ltd., Harlow.

Sagar, N., (2013), "Online Marketers Beware: M-commerce is changing your game”, Journal of Business and Management [online], (Issue 4), 20-26.

Schumacker, R. E., \& Lomax, R. G. (1996). A beginner's guide to structural equation modeling. Lawrence Erlbaum Associates, Inc.

Schermelleh-Engel, K., Moosbrugger, H., and Müller, H. (2003), “Evaluating the Fit of Structural Equation Models: Tests of Significance and Descriptive Goodness of-Fit Measures", Methods of Psychological Research Online, Vol. 8, No. 2, pp.23-74.

Selwyn, N., Gorard, S., Furlong, J., \& Madden, L.(2003.), "Exploring older adults' use of information and communications technology in everyday life", Ageing and Society, 23(5), 561 582.

Shaheen, M., Zeba, F., Chatterjee, N. and Krishnankutty, R. (2019), "Engaging customers through credible and useful reviews: the role of online trust", Young Consumers, Vol. 21 No. 2, pp. 137153.

Shankar, V., Smith, A. K., \& Rangaswamy, A. (2003). "Customer satisfaction and loyalty in online and offline environments", International Journal of Research in Marketing, 20(2), 153-175

Sheehan, K. and Hoy, M.G. (1999), "Flaming, complaining, abstaining: how online user respond to privacy concerns", Journal of Advertising, vol. 28, pp. 37-51, 1999.

Statista (2018). Global time spent on social media daily 2017| Statista [online]. Available from: https://www.statista.com/statistics/433871/daily-social-media-usage-worldwide/ [Accessed 3 Jun 2018].

Su Jung Kim, Rebecca Jen-hui Wang and Edward C. Malthouse. (2015), "The effects of adopting and using a brand's mobile application on customers' subsequent purchase behaviour", Journal of Interactive marketing. 31, 28-41.

Tan, E. and Leby Lau, J. (2016), "Behavioural intention to adopt mobile banking among the millennial generation", Young Consumers, Vol. 17 No. 1, pp. 18-31

Tsikriktsis, Nikos (2002), "Does Culture Influence Web Site Quality Expectations? An Empirical Study," Journal of Service Research, 5 (2), 101-112.

Yazdanparast, A., Joseph, M. and Muniz, F. (2016), "Consumer based brand equity in the 21st century: an examination of the role of social media marketing", Young Consumers, Vol. 17 No. 3, pp. 243-255.

Yin, R.K. (2003). Case Study Research, Design and Methods. Newbury Park, CA: Stage.

Vandenberg, R. J. (2006), "Statistical and Methodological Myths and Urban Legends", Organizational Research Methods, Vol. 9, No. 2, pp. 194-201.

Venkatesh, V., Ramesh, V., \& Massey, A. (2003), "Understanding usability in m-shopping", 
International Journal of Business Management and Economic Review

Vol. 5, No. 01; 2022

ISSN: 2581-4664

Communications of the ACM, Vol. 46, No. 12, pp. 53-36.

Venkatesh, V. (1999). "Creation of favourable user perceptions: Exploring the role of intrinsic motivation", MIS quarterly, 23(2), 239H260.

Wang, R. J. H., Malthouse, E. C., \& Krishnamurthi, L. (2015), “On the Go: How Mobile Shopping Affects Customer Purchase Behavior". Journal of Retailing, 91(2), 217-234.

Wu, J.H., and Wang, S.C. (2005), "What drives mobile commerce? An empirical evaluation of the revised technology acceptance model", Information \& Management, vol. 42, pp.719-729

W.S. Luan, T. Teo, (2009), "Investigating the technology acceptance among student teachers in Malaysia: An application of the Technology Acceptance Model (TAM)", Asia-Pacific Education Researcher, 18 (2) (2009), pp. 261-272 